\title{
Mediated electrochemical detection of electron transfer from the outer surface of the cell wall of Saccharomyces cerevisiae
}

\author{
Frankie J. Rawson ${ }^{\mathrm{a}, 1}$, Andrew J. Gross ${ }^{\text {b }}$, David J. Garrett ${ }^{\mathrm{b}, \mathrm{c}}$, Alison J. Downard ${ }^{\mathrm{b}}$, Keith.H.R. Baronian ${ }^{\mathrm{d}, *}$ \\ a Department of Chemistry, University of Canterbury, Private Bag 4800, Christchurch, New Zealand \\ ${ }^{\mathrm{b}}$ MacDiarmid Institute for Advanced Materials and Nanotechnology, Department of Chemistry, University of Canterbury, Private Bag 4800, Christchurch, New Zealand \\ c Department of Physics, The University of Melbourne, The David Caro Building, Corner Swanston Street and Tin Alley, VIC 3010, Australia \\ d School of Biological Sciences, University of Canterbury, Private Bag 4800, Christchurch, New Zealand
}

\section{A R T I C L E I N F O}

\section{Article history:}

Received 6 November 2011

Received in revised form 26 November 2011

Accepted 28 November 2011

Available online 7 December 2011

\section{Keywords:}

Osmium bipyridine complex

Mediator

Electrografting

Diazonium salt

Yeast electron transport

\begin{abstract}
A B S T R A C T
Catabolic electron transport processes in yeast are generally considered to be restricted to respiration, glycolysis and trans plasma membrane electron transport (tPMET) proteins. These processes are shielded from the external environment by the cell membrane and a thick cell wall. It has been recently proposed that electrons might be transferred directly from the yeast cell to electrodes. Here we provide the first experimental evidence for electron transfer from the external surface of a yeast cell to an electrode. The electrode has a stable mediator layer that is significantly thinner than the cell wall and unable to make direct contact with any known yeast redox centres. Current measured at the modified electrode in the presence of Saccharomyces cerevisiae is shown to originate both from exported soluble redox species and directly from the external surface of the cell wall.
\end{abstract}

(c) 2011 Elsevier B.V. All rights reserved.

\section{Introduction}

Electrogenic gram negative bacteria can transfer electrons from membrane cytochromes via pili and/or flagella to external electron acceptors $[1,2]$. These electron transfer systems have been demonstrated to be responsible for direct electron transfer to the anode in some microbial fuel cells [3]. In contrast, gram positive bacteria have a thick cell wall preventing close approach of membrane redox sites to an electrode. However, it was recently proposed that electron transport can occur across the cell walls of gram positive bacteria [4]. One possible mechanism could involve electron conduction from cell membrane reductases (tPmets) across the periplasm and through the cell wall by peptidoglycan, teichoic and/or teichuronic acid strands coordinated to reversibly reducible metal ions [4].

Yeast cells also have a thick (100-200 nm) cell wall constructed of polysaccharides and proteins $[5,6]$. Yeast cytochromes are located in the mitochondria and tPMETs are located in the cell membrane, which are enclosed by the cell wall. Hence to obtain an electrochemical response from yeast cells, it has been assumed that a mediator must

\footnotetext{
* Corresponding author. Tel.: +64 3364 2987x45723; fax: +64 33642590.

E-mail address: keith.baronian@canterbury.ac.nz (K.H.R. Baronian).

${ }^{1}$ Current address: Department of Chemical Engineering, University of Birmingham, Edgbaston, Birmingham, United Kingdom.
}

traverse the cell wall and interact with membrane and/or internal redox sites [7,8], or that the response originates from soluble electroactive species exported from the cell [9].

In comparison to bacteria, mediated electron transfer in yeast has received little attention, and has usually involved the use of freely diffusing mediators. However, in a recent study, Shkil et al. immobilised a yeast on an electrode modified with an osmium-complex redox polymer and showed that current was generated from the cells [10]. The authors were unable to specify the route of electron transfer to the osmium centre and concluded that the polymer might penetrate deeply into the cell wall to contact, or be in close proximity to, tPMET proteins. In contrast, Hubenova et al. [11,12] and Ducommun et al.[13] recently raised the possibility of electron transport across the yeast cell wall to explain their experimental findings but neither group attempted experimental verification.

In the present work we demonstrate direct electron transfer from the external surface of yeast cells to an electrode. We examine the electrochemistry of $S$. cerevisiae at electrodes modified with a mediator layer that is designed to prevent the mediator from penetrating the cell wall and interacting with internal redox sites. An osmium bipyridine complex was selected as the mediator based on the known activity of this class of complex [10,14-16]. The complex was covalently immobilised with a short tether to a very smooth pyrolysed photoresist film (PPF) substrate (rms surface roughness $<0.6 \mathrm{~nm}$ [17]) and the current associated with the Os ${ }^{\mathrm{II} / \mathrm{III}}$ couple was monitored in the presence of S. cerevisiae. 


\section{Experimental}

Sterilised phosphate buffered saline (PBS, $50 \mathrm{mM}$ phosphate buffer, $\mathrm{pH} 7$ and $0.1 \mathrm{M} \mathrm{KCl}$ ) was used for all electrochemical measurements. PPF samples [17] and osmium(II)bis-2,2-bipyridine(p-aminomethylpyridine)chlorido hexafluorophosphate [14] were prepared as described previously.

Electrochemistry was performed using an eDAQ potentiostat and PowerLab 2/20 with eDAQ EChem data acquisition software. Measurements with yeast cells were made at $35^{\circ} \mathrm{C}$; other measurements were made at RT. The modified PPF electrode was positioned horizontally in the bottom of the electrochemical cell [17] giving a working area of $0.50 \mathrm{~cm}^{2}$. Reference and auxiliary electrodes were $\mathrm{Ag} / \mathrm{AgCl}$ ( $3 \mathrm{M} \mathrm{KCl}$ ) and Pt, respectively. Atomic force microscopy (AFM) measurements and analysis were performed as previously reported [18].

4-carboxybenzenediazonium salt was prepared by adding $10 \mathrm{mM}$ 4-aminobenzoic acid in $0.5 \mathrm{M} \mathrm{HCl}$ to 1 molar equivalent of solid $\mathrm{NaNO}_{2}$. After 3 min the solution was transferred to the electrochemical cell and a 4-carboxyphenyl film was electrografted to the PPF by scanning from 0.2 to $-0.6 \mathrm{~V}$ (scan rate, $\nu=100 \mathrm{mV} \mathrm{s}^{-1}$ ) followed by $2 \mathrm{~min}$ at $-0.6 \mathrm{~V}$ and a final scan from 0.2 to $-0.6 \mathrm{~V}$. The modified electrode was rinsed with water and ethanol.

$\mathrm{Os}$ (bpy) ${ }_{2} \mathrm{Cl}(4 \text {-aminomethyl pyridine })^{+}$was coupled to the carboxyphenyl film by the method reported for its coupling to carbon nanotubes [14]. Prior to use, Osbipy electrodes were sonicated in PBS for 1 min and cycled 200 times in PBS from 0.0 to $0.6 \mathrm{~V}$ at $v=100 \mathrm{mV} \mathrm{s}^{-1}$ and then washed with Tween 80 . Between measurements with yeast cells, modified electrodes were sonicated for 2 min in Tween 80, rinsed with water and then ethanol.

S. cerevisiae (NCTC 10716 (ESR Ltd, Porirua, New Zealand) was maintained on yeast extract peptone dextrose (YEPD, pH 6.5, unbuffered) agar at $4{ }^{\circ} \mathrm{C}$. Cultures were grown in sterile YEPD broth ( $100 \mathrm{~mL}$ in $250 \mathrm{~mL}$ shake flasks, $35^{\circ} \mathrm{C}, 180 \mathrm{rpm}$ ). After $16 \mathrm{~h}$, cells (in stationary phase) were harvested by centrifugation at $4500 \times \mathrm{g}$ and washed twice in sterile PBS. To form a cell cream, the compacted cell pellet was re-suspended in an equal volume of PBS containing $2 \mathrm{mM}$ dextrose. Cyclic voltammograms (CVs) of yeast creams and supernatants were obtained at $\nu=2 \mathrm{mV} \mathrm{s}^{-1}$. The cream $(750 \mu \mathrm{L})$ was placed on the PPF electrode and CVs were performed immediately. The yeast cream was then transferred to a $1.5 \mathrm{~mL}$ Eppendorf tube and centrifuged at $12,000 \mathrm{rpm}$ for $12 \mathrm{~min}$. The supernatant was removed and transferred to the electrochemical cell for CV analysis. This procedure was repeated with cells incubated at $35^{\circ} \mathrm{C}$ for $3.5 \mathrm{~h}$.

\section{Results and discussion}

The procedure for preparation of Osbipy modified electrodes gives surfaces in which a thin flat film is covalently attached to the electrode by stable bonds. With this format, leaching of complex into solution where it could act as a soluble mediator, and/or penetration of the mediator layer through the yeast cell wall should not be possible. However to ensure that surface films did not incorporate any loosely attached material that could detach during measurements with cells, all modified electrodes were pre-treated prior to use. Pre-treatment involved sonication in PBS and potential cycling until the electrochemical response became constant [19]. As a final pre-treatment, electrodes were washed with the surfactant Tween 80 which decreased the background current and improved the signal-to-background ratio.

Fig. 1A shows CVs obtained in PBS at the Osbipy electrode. The $O s^{\mathrm{II} / \mathrm{II}}$ couple appears at $E_{1 / 2}=0.28 \mathrm{~V}$ vs $\mathrm{Ag} / \mathrm{AgCl}$ [14] and the peak currents were proportional to the scan rate, indicative of a surface confined species (Fig. 1B). The surface concentration of Osbipy complexes was determined from the charge associated with the anodic peak of CVs obtained at $100 \mathrm{mV} \mathrm{s}^{-1}$. The mean surface concentration of Osbipy on six PPF electrodes was $9.4 \times 10^{-11} \mathrm{~mol} \mathrm{~cm}^{-2}$ (standard deviation $(\mathrm{SD})= \pm 2.1 \times 10^{-11} \mathrm{~mol} \mathrm{~cm}{ }^{-2}$ ) which is similar to that
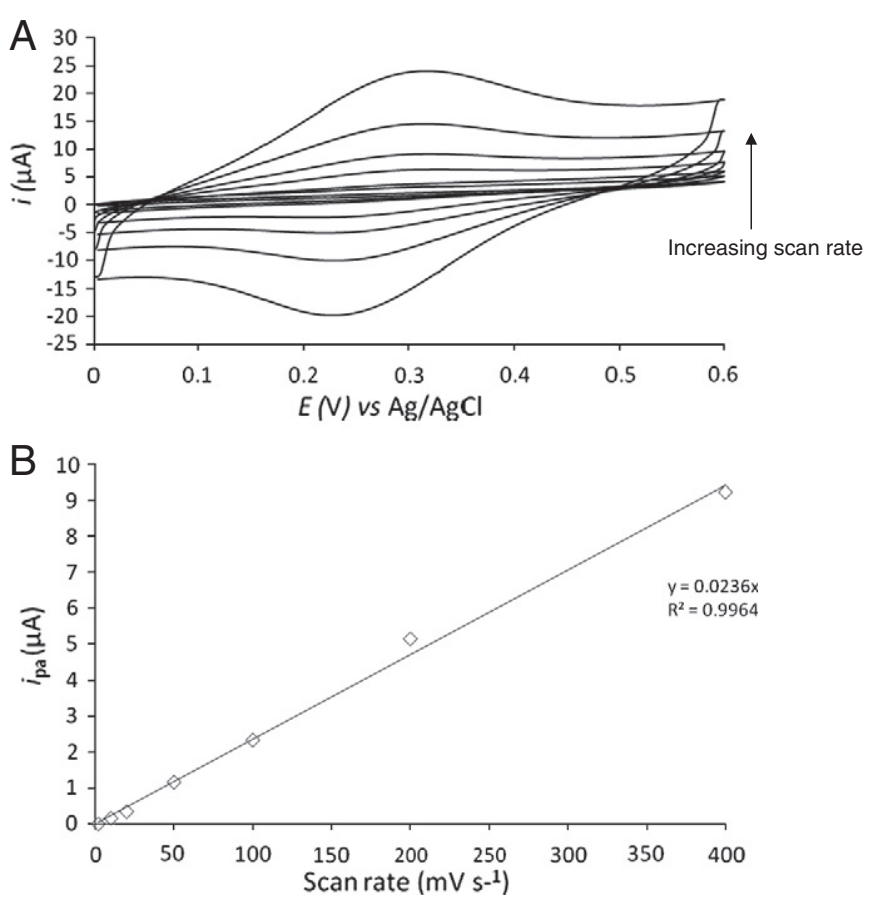

Fig. 1. (A) CVs obtained at a pre-treated Osbipy electrode at $v=2,5,20,50,100,200$ and $400 \mathrm{mV} \mathrm{s}^{-1}$; and (B) Plot of anodic peak current vs scan rate for the CVs in (A).

for a close-packed monolayer of complexes with the formula $\mathrm{M}$ (bipy) ${ }_{3}^{\mathrm{n}}+$ (approximately $1 \times 10^{-10} \mathrm{~mol} \mathrm{~cm}^{-2}[20]$ ).

AFM was used to characterise the thickness and morphology of the modifier layers. Depth profiling across a scratch in the films [18] gave average thicknesses of $5.9 \mathrm{~nm}(\mathrm{SD}= \pm 1.4 \mathrm{~nm})$ and $8.3 \mathrm{~nm}$ $(\mathrm{SD}= \pm 1.1 \mathrm{~nm})$ for the carboxyphenyl tether layer and the Osbipy/ carboxyphenyl film, respectively. The carboxyphenyl film is thus a multilayer; the increase in film thickness after coupling the Os complex indicates that close to a monolayer of Osbipy is attached to the tether layer. The surface roughness of the Osbipy/carboxyphenyl film was measured in five randomly selected $1 \mu \mathrm{m} \times 1 \mu \mathrm{m}$ squares on each of two film samples, giving rms values ranging from 5.0 to $25.0 \mathrm{~nm}$ (mean $=11.6 \mathrm{~nm})$. Comparing these values to the thickness of the yeast cell wall $(100-200 \mathrm{~nm})$ indicates that the surface roughness, presumably arising from protrusions in the film, could not lead to penetration of mediator through the yeast cell wall to make contact with the cell membrane i.e. it is not possible for electrons to be transferred from membrane redox sites directly to the Osbipy film.

The interaction of the Osbipy electrode with yeast cells was examined by obtaining CVs in the absence and presence of $S$. cerevisiae cells (Fig. 2A). Addition of cells increases the current for oxidation of Osbipy indicating that electrochemically generated Os ${ }^{\mathrm{III}}$ centres are reduced by the cells, and are subsequently re-oxidised at the electrode, leading to catalytic enhancement of the signal [21]. A control, in which the PPF electrode was modified with the carboxyphenyl tether layer only, did not show a peak in the presence of the cells confirming that Osbipy is required to mediate charge transfer.

We have previously demonstrated that the yeast Arxula adeninivorans can release soluble electroactive species [9] and we examined this possibility with $S$. cerevisiae. To distinguish between responses arising from the oxidation of exported soluble redox molecules and from the oxidation of cell wall components, the supernatant was analysed after separation from the cells by centrifugation of the cell cream. Fig. 2 shows that immediately after harvest, the oxidation current at the Osbipy electrode increases on addition of the cell cream, but the supernatant and blank (PBS) signals are the same $(p=0.79)$. Hence the current from the cell cream immediately after harvest cannot be attributed to soluble redox species. When the measurements were repeated after incubating 

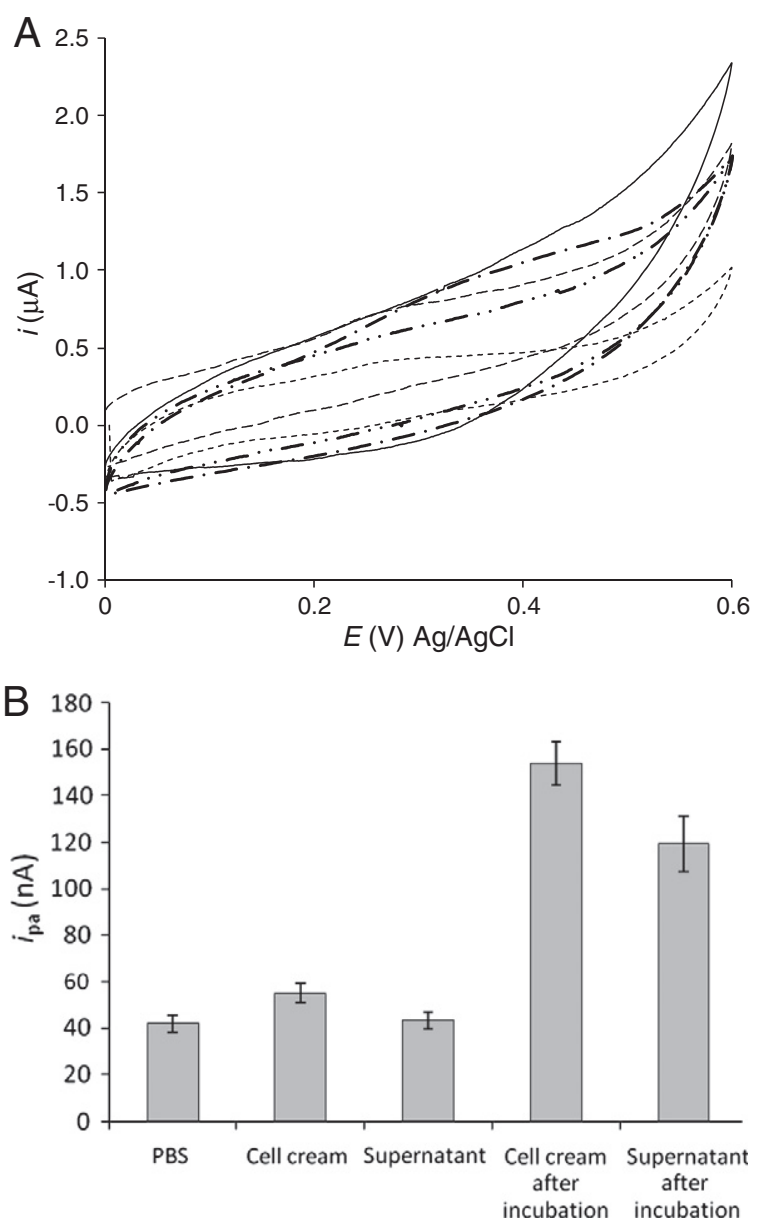

Fig. 2. (A) CVs recorded at an Osbipy electrode: in PBS (-----); with cell cream immediately after harvest (-- - ); with supernatant immediately after harvest $(-\cdots-\cdots-\cdots-)$; with cell cream after $3.5 \mathrm{~h}$ incubation $\left(-^{\left.-\cdot_{-} \cdot-\right)}\right)$; with supernatant after $3.5 \mathrm{~h}$ incubation (- ). (B) Mean anodic peak currents obtained for PBS blank, yeast cell cream and supernatant immediately after harvest, and after $3.5 \mathrm{~h}$ incubation. Data were obtained from three batches of cells using three different electrodes, and for each batch, triplicate CVs were obtained. Error bars represent the standard mean error $(n=9) \cdot\left(-\cdot \cdot_{-} \cdot \cdot\right)$

cells for $3.5 \mathrm{~h}$, the supernatant current was significant, which is consistent with the accumulation of (an) electroactive species exported from the cells. It is also clear from the cell cream signal that after $3.5 \mathrm{~h}$ the increase in the current is not solely due to the soluble species. We attribute this additional current (and that immediately after harvest) to direct electron transfer from $S$. cerevisiae to the modified electrode. The increase in this current with incubation period is expected: cells accumulate electrons during the incubation period and then divest these by electron transfer to the electrode.

Our conclusion that there is electron transfer from the external surface of the yeast cell wall to the modified electrode relies on eliminating all other sources of response. As a final check that a solutionbased mediator is not involved, retention of the Osbipy complex on the modified electrode over the duration of these experiments was examined. After making measurements with cells, CVs of a modified electrode (Fig. 3 ) revealed that the charge associated with the Os ${ }^{\mathrm{I} / / \mathrm{II}}$ couple had decreased and was only $(80 \pm 5) \%$ of that before use of the electrode with cells, i.e. the measured surface concentration of Osbipy complex was $80 \%$ of the initial concentration. However, the charge associated with the background current decreased by the same amount in the same experiments providing strong evidence that electrode fouling by cell products or components accounts for the apparent decrease in Osbipy concentration on the electrode surface and not from Osbipy detaching from the surface. (Note: based on comparisons between modified and unmodified PPF electrodes, loss of film

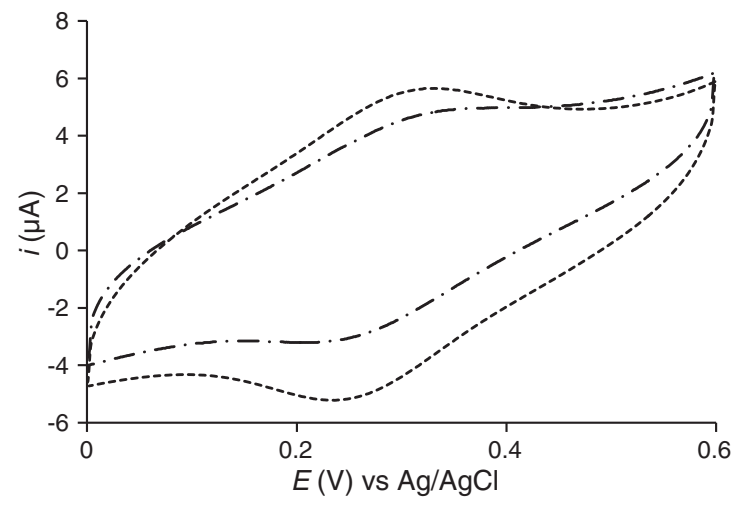

Fig. 3. $\mathrm{CVs}\left(\nu=100 \mathrm{mV} \mathrm{s}^{-1}\right)$ of an Osbipy electrode before (------ $)$ and after $\left(-^{-\cdot-\cdot-\cdot)}\right.$ exposure to cells.

from the electrode surface is expected to increase the background current and hence these changes are not consistent with film loss.)

In conclusion, we have obtained experimental evidence for the transfer of electrons from the external surface of the $S$. cerevisiae cell to the modified electrode. Speculation on the function of this process is intriguing. All cells must shed electrons from catabolism, for example by reducing oxygen or other terminal electron acceptors, by exporting reduced molecules such as ethanol from fermentation, or via cell membrane tPMETs. Perhaps the transfer of electrons across the cell wall is part of the systems the organism uses to divest itself of electrons from its catabolic processes. Our finding suggests that the role of the cell wall in cell function should be re-evaluated.

\section{Acknowledgements}

This work was supported by the RSNZ Marsden Fund (contract UOC 0605) and the MacDiarmid Institute for Advanced Materials and Nanotechnology. DJG thanks the Tertiary Education Commission for a doctoral scholarship.

\section{References}

[1] Y.A. Gorby, S. Yanina, J.S. McLean, K.M. Rosso, D. Moyles, A. Dohnalkova, T.J. Beveridge, I.S. Chang, B.H. Kim, K.S. Kim, D.E. Culley, S.B. Reed, M.F. Romine, D.A. Saffarini, E.A. Hill, L. Shi, D.A. Elias, D.W. Kennedy, G. Pinchuk, K. Watanabe, S. Ishii, B. Logan, K.H. Nealson, J.K. Fredrickson, Proceedings of the National Academy of Sciences 103 (2006) 11358.

[2] G. Reguera, K.D. McCarthy, T. Mehta, J.S. Nicoll, M.T. Tuominen, D.R. Lovley, Nature 435 (2005) 1098

[3] K. Rabaey, N. Boon, S.D. Siciliano, M. Verhaege, W. Verstraete, Applied and Environmental Microbiology 70 (2004) 5373.

[4] H.L. Ehrlich, Geobiology 6 (2008) 220.

[5] B. Aguilar-Uscanga, J.M. Francois, Letters in Applied Microbiology 37 (2003) 268.

[6] V. Dupres, Y.F. Dufrêne, J.J. Heinisch, ACS Nano 4 (2010) 5498.

[7] K.H.R. Baronian, A.J. Downard, R.K. Lowen, N. Pasco, Applied Microbiology and Biotechnology 60 (2002) 108.

[8] A. Heiskanen, C. Spégel, N. Kostesha, S. Lindahl, T. Ruzgas, J. Emnéus, Analytical Biochemistry 384 (2009) 11.

[9] N.D. Haslett, F.J. Rawson, F. Barriere, G. Kunze, N. Pasco, R. Gooneratne, K.H.R. Baronian, Biosensors \& Bioelectronics 26 (2011) 3742.

[10] H. Shkil, A. Schulte, D.A. Guschin, W. Schuhmann, Chemphyschem 12 (2011) 806.

[11] Y. Hubenova, R. Rashkov, V. Buchvarov, S. Babanova, M. Mitov, Journal of Materials Science 46 (2011) 7074

[12] Y.V. Hubenova, R.S. Rashkov, V.D. Buchvarov, M.H. Arnaudova, S.M. Babanova, M.Y. Mitov, Industrial and Engineering Chemistry Research 50 (2011) 557.

[13] R. Ducommun, M.F. Favre, D. Carrard, F. Fischer, Yeast 27 (2010) 139.

[14] F.J. Rawson, D.J. Garrett, D. Leech, A.J. Downard, K.H.R. Baronian, Biosensors \& Bioelectronics 26 (2011) 2383.

[15] S. Timur, U. Anik, D. Odaci, L. Gorton, Electrochemistry Communications 9 (2007) 1810.

[16] I. Vostiar, E.E. Ferapontova, L. Gorton, Electrochemistry Communications 6 (2004) 621.

[17] P.A. Brooksby, A.J. Downard, Langmuir 20 (2004) 5038.

[18] J. Lehr, D.J. Garrett, M.G. Paulik, B.S. Flavel, P.A. Brooksby, B.E. Williamson, A.J. Downard, Analytical Chemistry 82 (2010) 7027.

[19] S. Boland, K. Foster, D. Leech, Electrochimica Acta 54 (2009) 1986.

[20] H.D. Abruna, T.J. Meyer, R.W. Murray, Inorganic Chemistry 18 (1979) 3233.

[21] R.S. Nicholson, I. Shain, Analytical Chemistry 36 (1964) 706. 